\title{
Basic Petrological and Structural Analysis in the Zimbi Gold Area (East Cameroon)
}

\author{
Ntomb Yvan Demonstel ${ }^{1,3}$, Ndzie Mvondo Justin ${ }^{2,3, \text {, }}$, Ndong Bidzang Francois ${ }^{2}$ \\ ${ }^{1}$ Centre for Geological and Mining Research, Garoua, Cameroon \\ ${ }^{2}$ Ore Processing Laboratory, Institute for Geological and Mining Research, Yaounde, Cameroon \\ ${ }^{3}$ Department of Earth Sciences, University of Yaoundé I, Yaoundé, Cameroon
}

Email address:

nyvandemonstel@yahoo.fr (N. Y. Demonstel),ndziemvondojustin@yahoo.fr (N. M. Justin), fndongbidzang@gmail.com (N. B. Francois)

${ }^{*}$ Corresponding author

\section{To cite this article:}

Ntomb Yvan Demonstel, Ndzie Mvondo Justin, Ndong Bidzang Francois. Basic Petrological and Structural Analysis in the Zimbi Gold Area (East Cameroon). Earth Sciences. Vol. 9, No. 2, 2020, pp. 52-60. doi: 10.11648/j.earth.20200902.11

Received: December 26, 2019; Accepted: January 13, 2020; Published: February 20, 2020

\begin{abstract}
The plutono-metamorphic series of the locality of Zimbi, extends over a narrow strip of $135 \mathrm{~km}^{2}$ on the eastern edge of the gold district of Baden-Colomine in East Cameroon. The work carried out in this locality is based on a cartographic approach (processing of maps and Landsat-7 ETM + images), combined with a geological and mining survey on the ground using conventional tools. On the morphostructural level, we observe NE-SW oriented penetrative lineaments. The trajectories of these are deviated or not in contact with other less dense lineaments, organized in networks of directions N-S, NE-SW, ENE-WSW, E-W, NW-SE. Parallel to the main Cameroon Center Shear (N070E), the ENE-WSW network which induces a significant reversal of foliation on contact, defines a structuring dexter shear zone accompanied by NE-SW and EW satellite shear zones with dexter kinematics and NW-SE and NS of senestrial kinematics. The lithological diversity allows the facies of calc-alkaline granite to predominate. Zimbi's range of structural elements highlights a magmatic fluidity substituted in foliation. The foliation directed NE-SW, of dip (40-90 ${ }^{\circ}$ ) either towards the NW, or towards the SE; carries a linearization of stretch subméridienne. The folding that affects it is induced by two directions of compression perpendicular N-S to NE-SW and E-W to NW-SE, which define the voltage slots favorable to mineral concentrations by circulation of mineralizing fluids. The shear zones and the quartz-feldspathic veins, structures favorable to mineralization such as gold, secondarily affect this complex. These geomorphological, lithological and structural geology data make the plutono-metamorphic procession of Zimbi a privileged area for mining research, in the gold district of Baden-Colomine.
\end{abstract}

Keywords: Plutono-metamorphic, Zimbi Area, Morpho-structural, Gold Mineralization

\section{Introduction}

In Cameroon in general and in the Eastern Region in particular, precious stones (gold, diamonds, sapphires, etc.) are exploited mainly in the flats of rivers. These are alluvial ores from the surrounding rocks. Little attention has been paid to the primary mineralization feeding these alluvial placers. To go beyond the artisanal exploitation framework and develop a real mining industry, Cameroon has intensified the geological and mining research of its subsoil, through the PRECASEM project, to circumscribe possible polymetallic anomalies likely to attract potential mining companies of international scale. This paper presents the results of a preliminary exploration to geologically develop an inventory of the potential for gold concentration in the rocks of the Zimbi locality. It is supported by satellite imagery, topographic and geological maps as well as geological field surveys, petrographic observations and structural analysis, data acquired through a conventional geological prospecting approach help with conventional tools.

\section{Geological Setting}

Zimbi is situated within the Adamawa-Yadé domain [1-3], in the Central African Fold Belt (CAFB; [4, 2]) in Cameroon. The CAFB is the southernmost part of the conceptual pre-Neoproterozoic Saharan "metacraton", which occupied 
the north-central part of Africa, i.e. the entire region of the African continent extending north of the Congo Craton and east of the West African Craton [5, 3]. Three lithostructural domains have been identified in the Pan-African fold belt in Cameroon: the Yaounde, Adamawa-Yade, and Northwestern Cameroon domains [2, 3]. The Adamawa-Yade domain extends east of the Tchollire-Banyo fault (Figure 1). It is dominated by $640-610 \mathrm{Ma}$, syn- to late-collisional high-K calc-alkaline granitoids, which intrude high-grade gneisses [2, 6, 3]. This domain is dissected by large NE-striking transcurrent faults thought to be extensions of the major shear zones of north-eastern Brazil. Reference [2] classified the rocks of the Adamawa-Yade domain into three main groups: (a) large supracrustal blocks of Palaeoproterozoic metasedimentary rocks and orthogneiss with contributions from an Archaean crust similar to the Ntem Complex, (b) 612-600 Ma, low- to medium-grade metasedimentary and metavolcanoclastic rocks [7]; and (c) 640-610 Ma syn- to late-tectonic granitoids of transitional composition and crustal origin [2, 3]. Recent geological investigation in the studied area have recognized migmatites and orthogneisses intruded by syn-to post-tectonic granodiorites and granites [8].

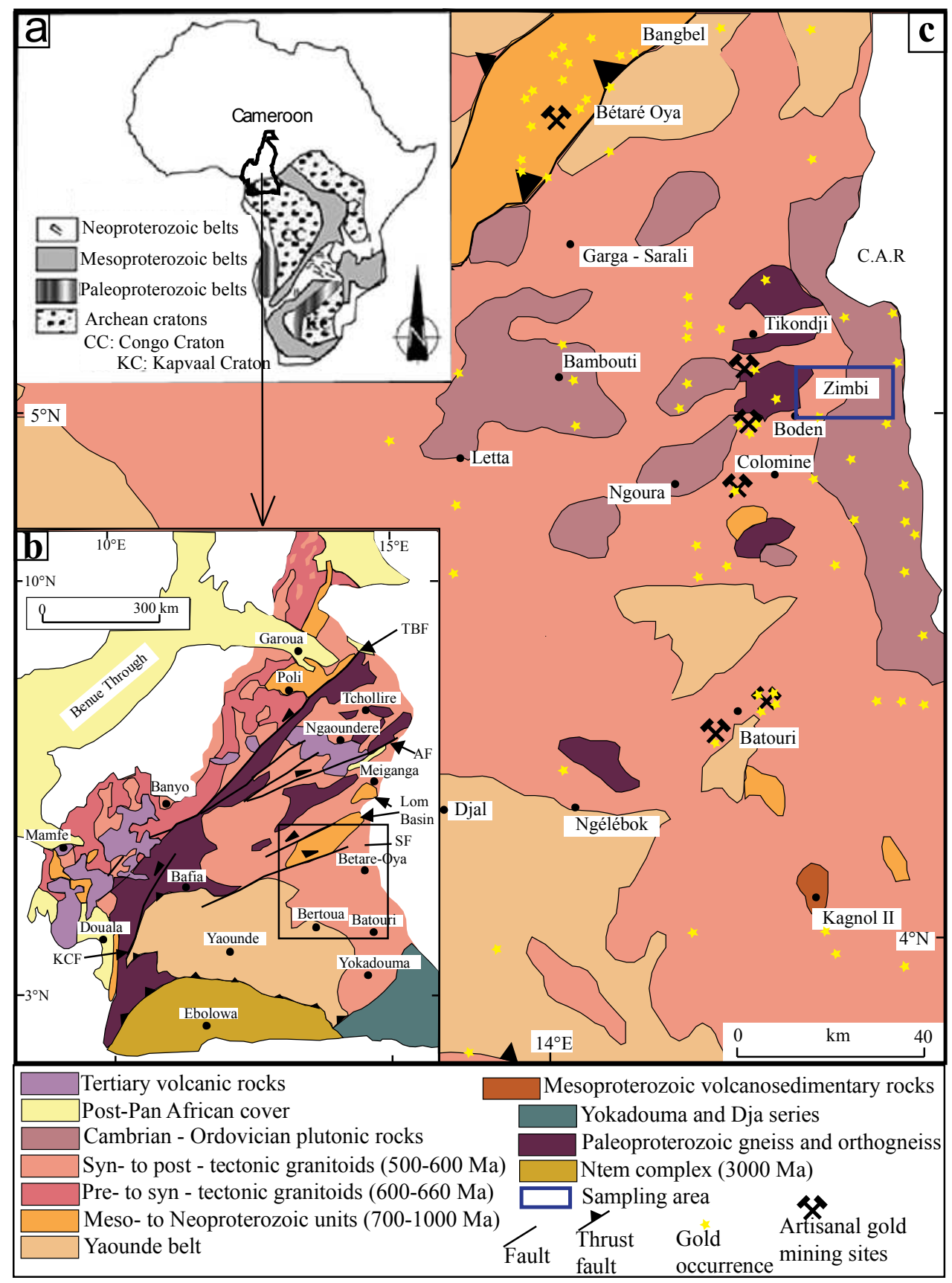

Figure 1. Geology of south-eastern Cameroon. (a) Geological diagram showing the position of the Congo and Kalahari cratons in Africa (Batumike et al., 2009). (b) Geological map of Cameroon (modified after Toteu et al., 2001). The Central African Shear Zone is defined by a system of NE-trending faults comprising Tchollire-Banyo Fault (TBF), Adamawa Fault (AF), Sanaga Fault (SF) and Kribi-Campo Fault (KCF). (c) Regional geological map of southeastern Cameroon, showing artisanal gold mining sites and other reported gold indications (Toteu et al., 2001, 2006c). 


\section{Methodology}

This work relies entirely on a cartographic approach based on two aspects; the processing of the maps at the image processing laboratory of the Institute of Geological and Mining Research and the geological and mining survey in the field. The combination of these two approaches made it possible to release a base map for an advanced mining study.

The cartographic database used in this study includes geological maps established at 1/200 000 for the localities of Batouri [1] and Betaré-Oya [9]. Photogeological maps established at 1/200 000 for these localities were also used. To these data are added two Landsat-7 ETM + images (scenes 184-56 / 57) acquired on March 2, 2012, corresponding to the long dry season. These satellite images have been chosen because of their spectral and spatial characteristics allowing a good structural mapping on a small scale. The methodology for extracting lineaments is from references [10] and [11].

The preliminary phase of satellite image processing consists of eliminating radiometric noise in the ETM + bands and correcting geometric distortions in order to make them perfectly superimposable on existing thematic maps (topographic, geological and photogeological maps). The $\mathrm{ETM}+$ images used here appear without major radiometric noise and therefore do not require significant processing. The geometric correction was carried out from ten points of amer distributed homogeneously over the whole of the study area.

Principal component analysis (PCA), image combinations, and directional spatial filtering have been applied to image enhancement $[10,12,13]$. The raw images and the generated neochannels were used as input images for the application of techniques more relevant for the enhancement of linear structures. These include filtering techniques (Sobel filters and $7 \times 7$ gradient) that have been applied to the ETM +5 , $\mathrm{ETM}+7, \mathrm{ETM}+5 / \mathrm{ETM}+4, \mathrm{ACP} 1123$ and ACP1567 bands $[10,11,14,15]$.

The phase of control and validation of geological accidents extracted from digital processing of ETM + images is essential to judge the relevance of the method used. The structures identified from the Landsat 7 ETM + images were subjected to a frequency analysis where the main directions were compared with those of the accidents recorded on the geological map. Auxiliary data from geological and photogeological maps have been compared to linear structures or morpho-structural alignment extracted from satellite images to give them structural significance [16-19]. When the anthropogenic origin of a linear structure has been proved (roads, tracks, limits of forests or cultivated areas, etc.), it has been removed. Thus, those remaining are likely to be a fracture [8, 20-22]. The detailed fracture network map obtained in this study is certainly not exhaustive, but is representative of the fracturing of the Zimbi region (Figure 2). Fracture networks were therefore analyzed using statistical and geostatistical analysis techniques.

Direct observation in the field consisted of a location survey, photographing and measuring the structural elements identified. To take the measurements, we used the classical method of measuring with the compass on the object and we thus measured the direction and the embedding of the linear elements (lineation, axis of the folds...) and the directions and dips for the elements planar (foliation, schistosity, shear plane...). To overcome observation errors and for optimum statistical data processing, several measurements were taken on the same structural elements. The brief relative chronology of the structural elements as well as the determination of the different lithological assemblages of the sector have been clearly defined in the field. The various petrographic types have also been distinguished and their description outlined. Finally, all artisanal gold mining sites have been identified and mapped.

\section{Results and Discussion}

\subsection{Morphostructural Data}

The analysis in Figure $2 b$ shows the complexity of geological structures that can control the location and geometry of gold deposits. It emerges indeed penetrating (tight) lineaments globally oriented NE-SW and representing the foliation. The trajectories of this one are deviated or not to the contact with other less dense lineaments corresponding to fractures and faults which are more or less organized in networks of global directions NS, NE-SW, ENE-WSW, EW, NW-SE. Parallel to the main Cameroon Center Shear (N070E, $[23,24])$, the ENE-WSW network which induces a significant reversal of foliation on contact defines a structuring dexter shear zones accompanied by shear zones NE-SW and EW satellites of dextral kinematics and NW-SE and NS of kinematic sinistrus (Figure 2b). Such shear zones are also targets for gold mineralization to guide field prospecting [25-28].

The structural sketch (Figure 3 ) made by superimposing the Landsat-7 ETM + image and the topographic and geological maps specifies the structuring of the bedrock of the explored site, as it reproduces the NE-SW direction of the foliation trajectories that draw locally folds as well as the aforementioned fracture system. It also shows that the hydrographic network sheltering exploited gold placer is structurally guided, as it follows sometimes the trajectories of foliation, sometimes the course of fractures [29-32].

\subsection{Lithology}

Observed on the beds of watercourses or forming slabs at the top of some hills, the bed-rock of the sector considered is armed with a porphyritic granite (Figure 3a) to which a pronounced deformation confers the appearance of an orthogneiss to net and multiform foliation (Figure 3c). The wafer facies, accompanied by petrographic types such as aplites, pegmatites, basic enclaves (Figure 3d), veins of varied nature (Figure 5), is a granite because of predominant calc-soda feldspars. However, a preponderant potassic feldspar sub-facies is observed sporadically in the massif on 
which the area of the largest artisanal mining sites extends (Figure 3b). Porphyritic granite is associated in the form of veins (likely to contain gold) of variable dimensions (centimeter to pluridecametric thickness) and parallel or intersecting on the foliation: (1) a fine-grained and foliation-like aplitic facies marked by preferential orientation of minerals (feldspars, biotite...); (2) pegmatites; (3) basic enclaves in the form of massive amphibolites (Figure 3d) or coiled in the weft rock (Figure 3b) and (4) quartz veins larding the entire study area. By comparing the lithology of the study area with the formations of the same age of the surrounding areas whose mining activity is sufficiently advanced, we note that there is a lithological difference between the Zimbi formations and those of Djal, Bétaré-Oya, Bangbel and Dimako [1, 33-35] (Figure 1). In fact, the metamorphic and magmatic formations of these regions consist of metasediments and migmatites for pan-African paraplegic rocks, and granitoids for orthodrographic rocks belonging either to the formations of the Yaounde group or to the post-Panafrican cover. The lithology of the study area is comparable to the igneous and meta-igneous formations of Batouri [9, 36], Ngoura [37], and Colomine [8].

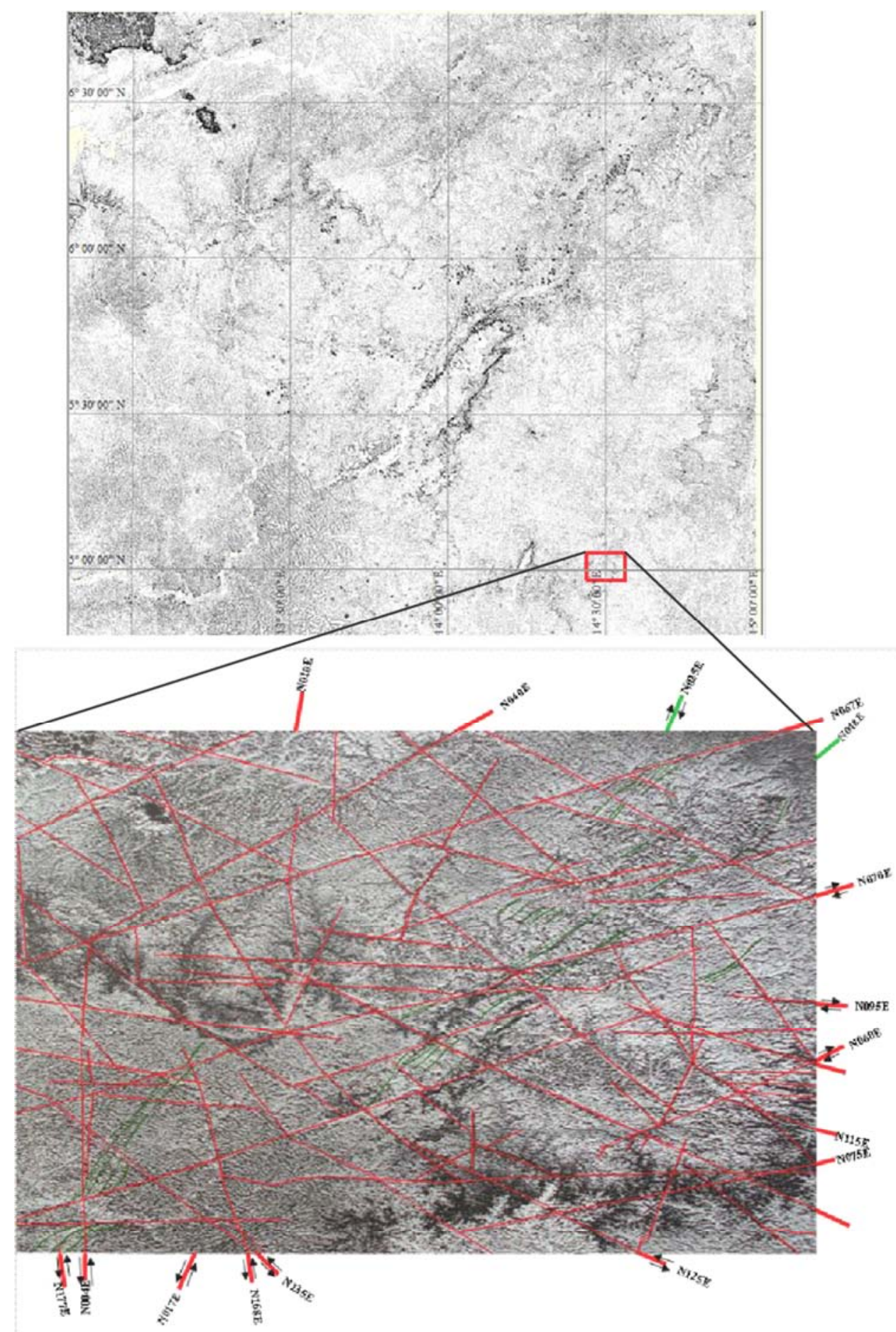

Figure 2. Map of the main lineaments of the Zimbi region based on analysis of the Landsat 7 ETM + image (path: 184; row 056). 

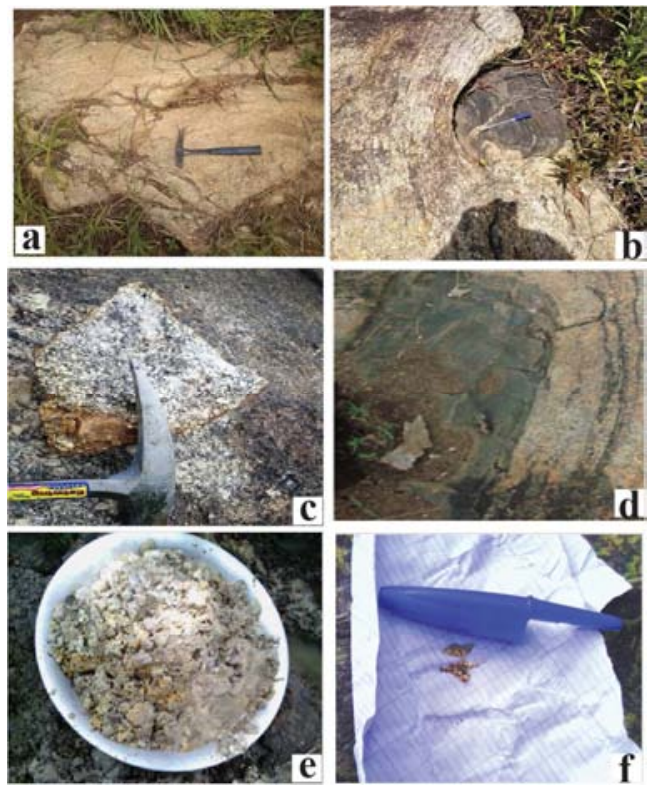

Figure 3. Principal lithological facies of the zone of Zimbi.
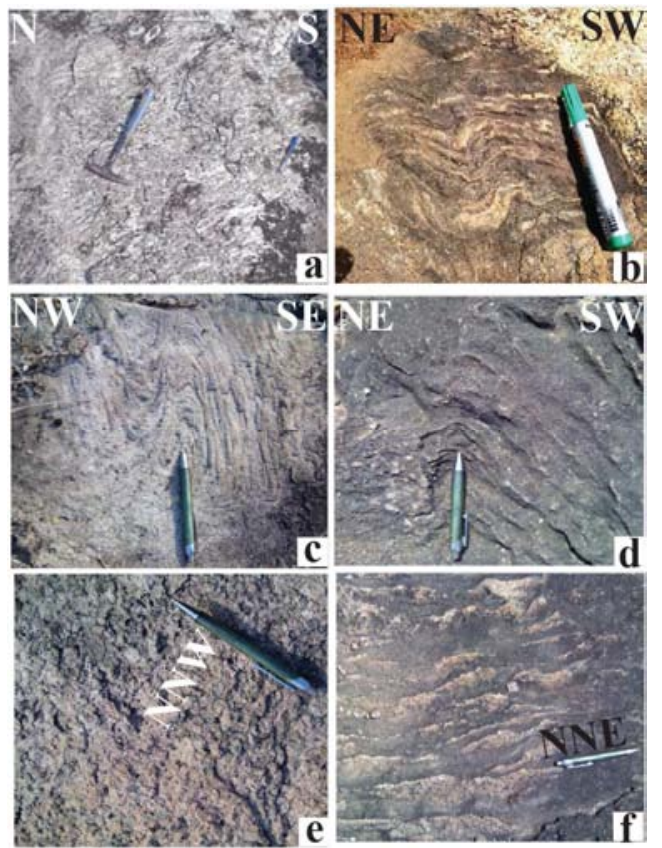

Figure 4. Main ductile structural elements of the Zimbi area.

\subsection{Structural Analysis}

The granite concerned and its lithologic procession present structures whose earliest corresponds to the foliation. It is a multifaceted planar structure. Indeed, a primary magmatic fluidity is underlined by aligned feldspar prisms (Figure 4a), forming a planar fabric, witnessing an emplacement of the granite massif in a dynamic context [38]. By lithological differentiation under stress during the intrusion, this magmatic fluidity becomes a more or less convoluted foliation (eyelike orthogneiss) as illustrated in Figure $4 b$ or clearly expressed through a millimetric to centimeter bedding (alternation of quartzo-feldspar beds and biotitic ferromagnesians). At the outcrop, the foliation is often reinforced by a lithologic ribbon where weft facies, aplitic fine-grained facies, pegmatites or basic enclaves alternate in parallel "banks". The foliation thus described corresponds to a zone of weakness along which the mineralizing fluids (including auriferous) can flow [39]. The foliation has a preferential direction NE-SW (Figure 4) and a dip generally strong $\left(40-90^{\circ}\right)$ either NW or SE. Other directions (NS, NW-SE, EW...) of the foliation diverge from this regional orientation, thus highlighting the folding which affects it and which is induced by two perpendicular compression directions NS to NE-SW and EW to NW-SE (Figure 4c, 4d, 6). Compression directions, which determine the orientation of the favorable tension slots at mineral concentrations by circulating mineralizing fluids [40, 41, 42, $43,45]$. The foliation surface carries a NNW-SSE NNE-SSW directional lineation (Figure 4e). It is also locally affected by micro-waves whose axis (crenulation lineation) tends to parallelize the stretching lineation (Figure 4f).

The phenomenon of stretching in the granite complex considered is also manifested by flanges (Figure 5c); these meet at the level of the pegmatites and basic enclaves which reinforce the foliation. The extrusion of these petrographic types is maximum in the NE-SW direction and minimum in the NW-SE direction. Stretching and strands are elongation structures within which the crystallizations of gold-bearing quartz can be carried out in particular at the level of the necks of strands [44].

The shear zones, structures often hosting mineralization such as gold, secondarily affect the granite complex. These are ductile or brittle-ductile shear zones often healed by veins of aplites, pegmatites, quartz, etc. (Figure 6). At the outcrop, the orientation of the shear zones is similar to those of the fractures and recesses identified in the satellite image analysis, namely EW, ENE-WSW, ESE-WNW and NS (Figure 5a, 5b).. Two types of quartzo-feldspathic veins have been distinguished according to their angular relationship with foliation, their geometry and their relative age. The veins parallel to S2 have thicknesses which vary between 5 and 10 $\mathrm{cm}$, for a length which reaches the decametre (Figure 5d, 5f). Some of these veins are extruded and form more or less separate tubes. The oblique veins at the foliation have practically the same thicknesses as the preceding ones but have a length which rarely reaches the meter (Figure 5c, 5e). The angle they make with the foliation varies from 35 to $104^{\circ}$. They are slightly or not deformed and are probably quite late compared to the other type of veins. The structural study of the mineralized indices of the major gold provinces [40-43, 45] shows a close link between the development of structures (shear zones, fractures, faults...) and the establishment of gold mineralization. Folding hinges are often a prime location for the development of shear zones and the establishment of mineralization. Examples include the Musselwhite deposit from Opapimiskan Lake in Ontario [46] and the Geraldton deposit in Ontario [41]. The structural sketch of the Zimbi gold zone (Figure 6) shows similarities with those of these large metallogenic provinces. 

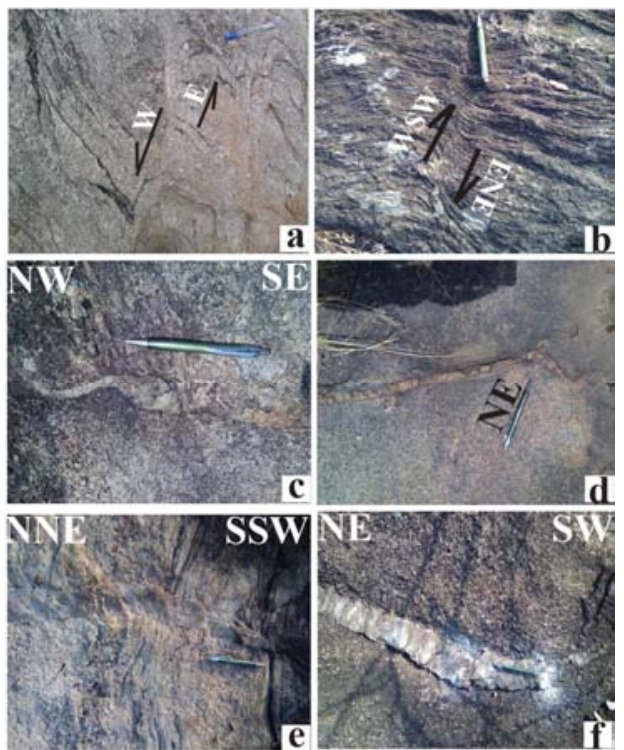

Figure 5. Main fragile-ductile structural elements of the Zimbi zone.

\subsection{Gold Potential of Prospected Rocks}

Several works $[10,22,47]$ have shown the major contribution of ETM + images for the recognition of discontinuous reservoirs. These images offer both spectral and spatial resolution suitable for good geological study [29-32]. A large number of mineral deposits are located in areas of tectonic activity such as ancient basins or orogenic belts. It is therefore not surprising that the vast majority of mineral deposits are more or less under the influence of its geological structures. From the point of view of exploration and mining, the potential impact of such structures, small or large scale, on the entire project should not be overlooked since they affect most aspects of the project including content control and resource estimation. In the Zimbi zone, the explored granite complex offers the potential for gold mineralization through: (1) positive alluvial prospecting data (batches data) from the terraces downstream and at the source of the rivers draining the massif, evidence of gold mineralization of some of its rocks (Figure 7); (2) gold-bearing boulders of artisanal gravel excavated from the edges of fractures affecting the granite and quartz-veined veins that leave an alignment of automorphic quartz crystal geodes organized as a palisade (Figure 3e); (3) the angularity of the elements constituting the gravel exploited, proof of their transport runs from their granite feed source (Figure 3e); (4) the numerous veins of aplite, pegmatite, quartz larding the granite massif in several directions and highlighting fractures and shear zones, sites of preferential concentration of sulphides and gold. The association of gold with pyrite suggests transport in the form of bisulfide complex, which is a typical means of transport in mesothermal deposits $[49,50]$. The destabilization of the bi-sulphide complex, which leads to pyrite formation and gold precipitation, controlled by structural or lithological factors $[42,50,51]$.

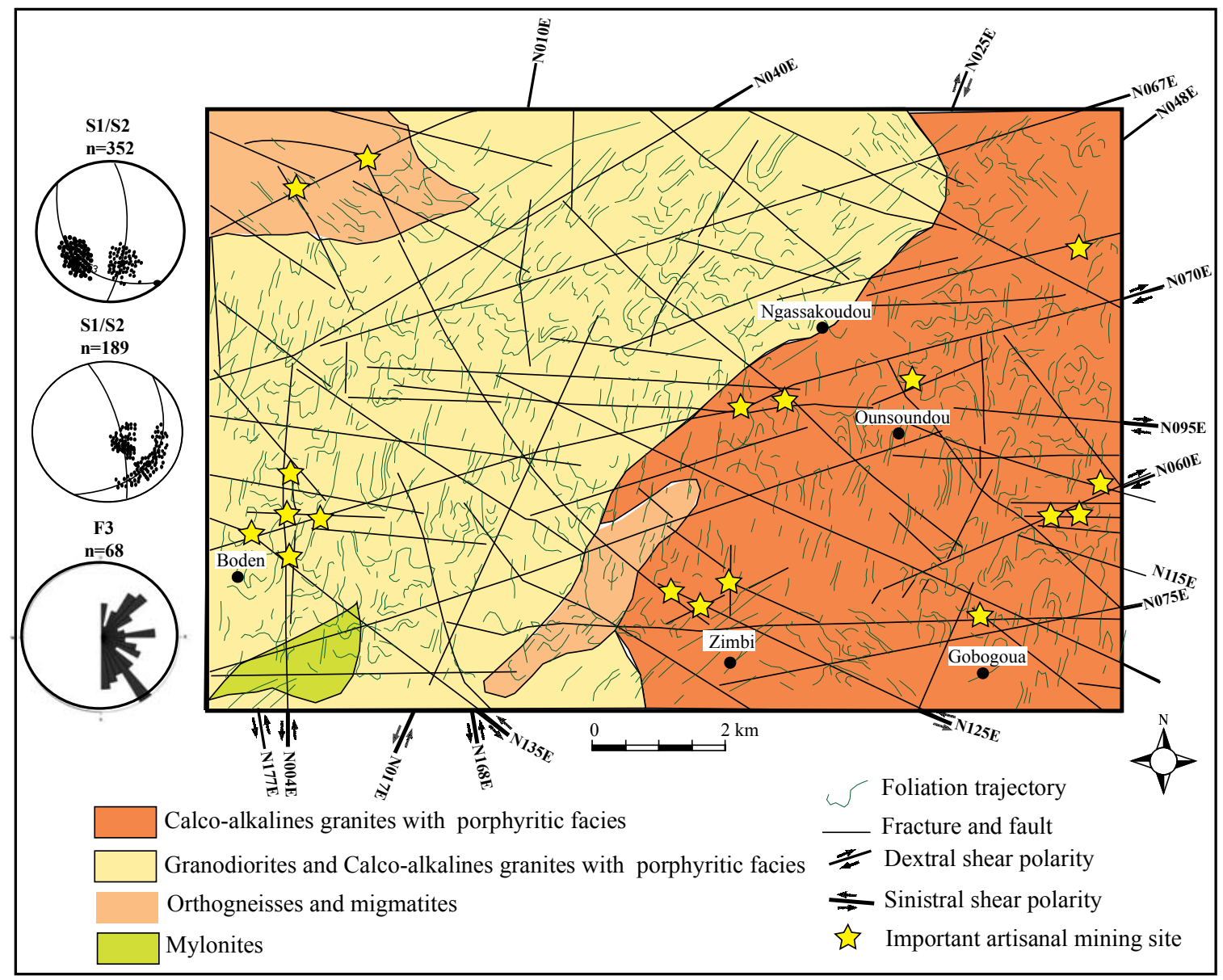

Figure 6. Structural sketch of the Zimbi gold zone. 


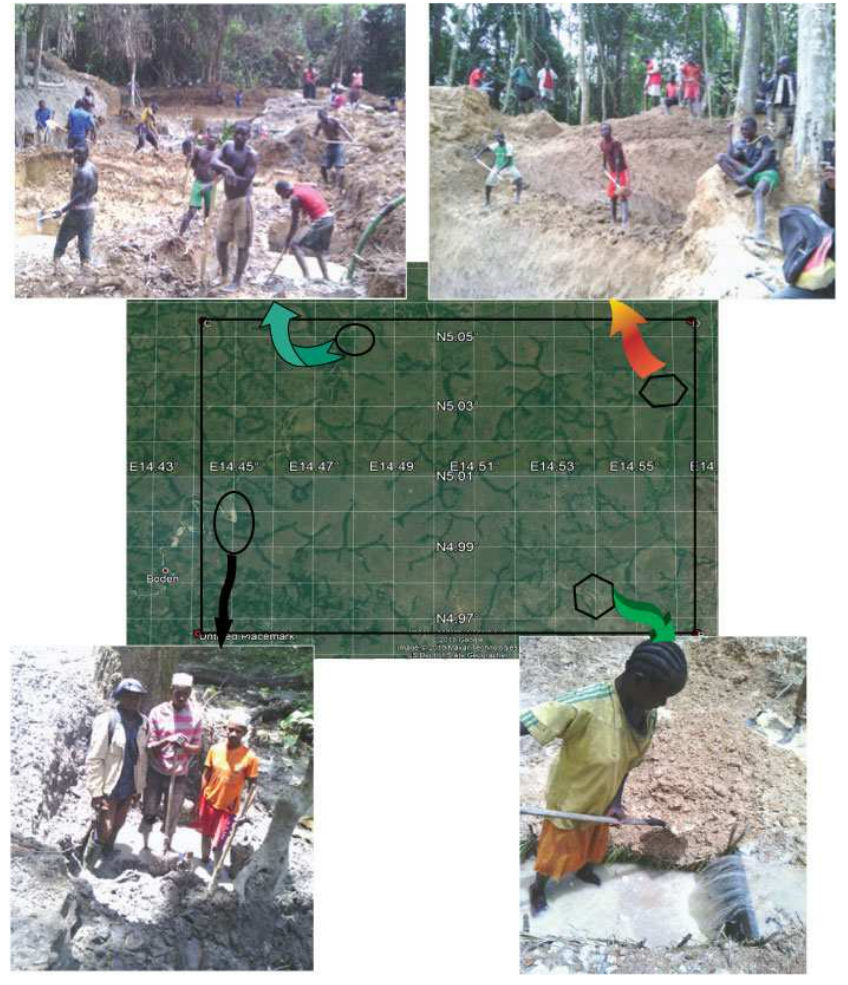

Figure 7. Main Gold Mining Sites in the Zimbi Gold Zone.

\section{Conclusion}

Thanks to the following article, it was possible to come up with a review of surface geology, through the screening of morpho structural, lithologic and tectonic characteristics giving way to auriferous potentialities and to the control of such mineralisation. The results obtained show that the Zimbi hydrographic network depends on structures, as the streams to place gold flow according to either the way of the regional foliation or of the fractures that affect them; the bedrock of the explored area is made up of granits crossed by potentially auriferous aplite, pegmatite, elementary rock and quartz seams; the granitic lump and its seamy cortege, more often than not veiled by the vegetal hardiness cover up that limits direct access to their outcrop, either carry or are a symbol of the structures (breaks, foliation, folds...) that control the location and the geometry of the ore gold coverts. The interpretation of satellite images made it possible to come up with a less complex definition of mineralised targets, as well as the prediction of their spatial extension, often obstructed by pedagogic coverage and the overlay of structures in the rocks.

\section{References}

[1] Asaah, A. V., Zoheir, B., Lehmann, B., Frei, D., Burgess, R., \& Suh, C. E., 2014. Geochemistry and geochronology of the $\sim 620$ Ma goldassociated Batouri granitoids, Cameroon. International Geology Review, 57, 1485-1509.

[2] Toteu, S. F., Penaye, J., \& Djomani, Y. P. (2004). Geodynamic evolution of the Pan-African belt in central Africa with special reference to Cameroon. Canadian Journal of Earth Sciences, 41 (1), 73-85.

[3] Van Schmus, W. R., Oliveira, E. P., Da Silva Filho, A. F., Toteu, S. F., Penaye, J., \& Guimarães, I. P. (2008). Proterozoic links between the Borborema province, NE Brazil, and the central African fold belt. Geological Society, London, Special Publications, 294 (1), 69-99.

[4] Toteu, S. F., Van Schmus, R. W., Penaye, J., \& Michard, A. (2001). New U-Pb and Sm-Nd data from north - central Cameroon and its bearing on the pre - Pan - African history of central Africa. Precambrian Research, 108, 45-73.

[5] Abdelsalam, M. G., Liégeois, J. P., \& Stern, R. J., 2002. The saharan metacraton. Journal of African Earth Sciences, 34 (3-4), 119-136.

[6] Njiosseu, E. L. T., Nzenti, J. P., Njanko, T., Kapajika, B., \& Nédélec, A. (2005). New UPb zircon ages from Tonga (Cameroon): coexisting Eburnean-Transamazonian (2.1 Ga) and Pan-African (0.6 Ga) imprints. Comptes Rendus Geoscience, 337 (6), 551-562.

[7] Toteu, S. F., Penaye, J., Deloule, E., Van Schmus, W. R., \& Tchameni, R. (2006). Diachronous evolution of volcano sedimentary basins north of the Congo craton: Insights from $\mathrm{U}-\mathrm{Pb}$ ion microprobe dating of zircons from the Poli, Lom and Yaoundé groups (Cameroon). Journal of African Earth Science, 44, 428-442.

[8] Wambo T. J. D., Ganno S., Djonthu L. Y. S., Kouankap N. G. D., Fossi H. D., Tchouatcha M. S., Neznti J. P., 2018. Geostatistical and GIS analysis of the spatial variability of alluvial gold content in Ngoura-Colomines area, Eastern Cameroon: Implications for the exploration of primary gold deposit. Journal of african earth Sciences, 142, 138-157.

[9] Vishiti A, Suh CE, Lehmann B, et al. Mineral chemistry, bulk rock geochemistry, and S - isotope signature of lode - gold mineralization in the Bétaré Oya gold district, south - east Cameroon. 2017. Geological Journal, 1-18.

[10] Youan Ta M. (2008) Contribution de la télédétection et des systèmes d'informations géographiques à la prospection hydrogéologique du socle précambrien d'Afrique de l'Ouest: Cas de la région de Bondoukou Nord Est de la Côte d'Ivoire. Thèse de doctorat unique, Université de Cocody-Abidjan (Côte d'Ivoire), $236 \mathrm{p}$.

[11] Ouattara G, Koffi G. B., Yao K. A., 2012. Contribution of Landsat 7 ETM+ imagery to the litho-structural mapping of east-central Côte d'Ivoire (West Africa) International Journal of Innovation and Applied Studies, 1, 1, 61-75.

[12] Joly F. (1986): Les cartes géomorphologiques. Géochroniques, $\mathrm{n}^{\circ}$ 19, pp23-26. Paris.

[13] Robin M. (1998) La Télédétection: Des satellites aux systèmes d'information géographiques. Fac Géographie, Univ. Nantes, France), 319 p.

[14] E. Nezry, A. Lopez, and R. Touzi, 1991. "Detection of structural and textural features for SAR images filtering," in proceeding of IGARSS 91, pp. 2169-2172.

[15] Himyari, S. M. Hoepffner, C. Benzakour, M. et Hadani, D. E. (2002) Etude structurale du haut atlas oriental Maroc) à l'aide de l'analyse linéamentaire des images HRV XS) de Spot. Télédétection, 02, 4, 243-253. 
[16] Yésou, H. Pion, J. C. Besnus, Y. et Saint Jean, R. (1993) Amélioration des données SPOT pour la cartographie structurale en milieu tropical. Exemple de la région des chapeaux de fer de Pagala Togo). IIIèmes Journées Scientifiques du Réseau Télédétection UREF, Toulouse, 13-16 novembre 1990, pp. 143-164. In: J. M. Dubois, F. Blasco dir), Outil microinformatique et Télédétection de l'évolution des milieux, PUQ/AUPELF UREF. Ed., 492 p.

[17] K. F. Kouamé, P. Gioan, J. Biémi, and K. Et-affian (1999) Méthode de cartographie des discontinuités-images satellitales: Exemple de la région semi-montagneuse à l'ouest de la Côte $\mathrm{d}$, Ivoire. Télédétection, vol. 2, pp. 139-156. et al., 1999

[18] Lasm T. (2000) Hydrogéologie des réservoirs fracturés de socle: Analyses statistiques et géostatistique de la fracturation et des propriétés hydrauliques. Application à la région des montagnes de Côte d'Ivoire Domaine Archéen). Thèse de doctorat, Université de Poitiers, 272 p.

[19] Ndong, B. F., Sobdjou, K. C., Mero Y., Ntomba M. S., Nzenti J. P., Mvondo O. J., 2016. Origin and Tectonic Framework of the Ngovayang Iron Massifs, South Cameroon. Science Research 4, $1,11-20$.

[20] Lasm, T. et Razack, M. (2001) Lois d'échelle dans la fracturation des roches dures cristallines et dans le réseau hydrographique associé. Compte Rendu Académie des Sciences Paris, Science de la Terre et des planètes, $\mathrm{n}^{\circ} 333$, $\mathrm{p}$. 225-232.

[21] Lasm T., Kouamé F., Soro N., Jourda J. P. R. \& Biémi J. (2004) Analyse géostatistique de la fracturation extraite de l'imagerie spatiale aéroportée et satellitaire. Application à la région de Man-Danané (Ouest de la Côte d'Ivoire). Revue Ivoirienne des Sciences et Technologie 5, p. 135-154.

[22] Kouamé K. F., Akaffou A. G., Lasm T., De Dreuzy J. R., Davy P. \& Bour O. (2005) Simulation des écoulements dans les réservoirs fracturés: application au socle Archéen de Touba (Nord-Ouest de la Côte d'Ivoire). Actes du Colloque Internationale SITIS 05, Yaoundé (Cameroun), 27 Nov.-1er Déc. 2005, p. 39-46.

[23] Ganwa, A. A., Frisch, W., Siebel, W., Kongyuy Shang, C., Mvondo Ondoa, J., Muharrem Satir, Tchakounté Numben, J., 2008. Zircon $207 \mathrm{~Pb} / 206 \mathrm{~Pb}$ evaporation ages of Panafrican metasedimentary rocks in the Kombe'-II area (Bafia Group, Cameroon): Constraints on protolith age and provenance. Journal of African Earth Sciences 51, 77-88.

[24] Tchakounté, J. N., Toteu, S. F., Van Schmus, W. R., Penaye, J., Deloule, E., Mvondo Ondoa, J., Bouyo Houketchang, M., Ganwa, A. A., White, W., 2007. Evidence of ca 1. 6-Ga detrital zircon in the Bafia Group (Cameroon): Implication for the chronostratigraphy of the Pan-African Belt north on the Congo craton. C. R. Geoscience 339, 132-142.

[25] Faure, S., 2001. Analyse des linéaments géophysiques en relation avec les minéralisations en or et métaux de base de l'Abitibi. Rapport, Projet CONSOREM 2000-03A, 26 p.

[26] Marshall, B. 1978. The lineament-ore association. Economic Geology, 73: 942-945.

[27] Kutina, J. et Fabbri, A. 1971. Relationship of structural lineaments and mineral occurrences in the Abitibi area of the Canadian shield. Geological Survey of Canada, Paper 71-9, $33 \mathrm{p}$.

[28] O’Driscoll, E. S. T. 1990. Lineament tectonics of Australian ore deposits. Dans Hughes, F. E. (éd.): Geology of the Mineral Deposits of Australia and Papua New Guinea, p. 33-41.

[29] Tweed S. O., Leblanc M. C., Webb J. A. and Lubczynski M. W. (2007) Remote sensing and GIS for mapping groundwater recharge and discharge areas in salinity prone catchments, southeastern Australia. Hydrogeology Journal, $\mathrm{n}^{\circ}$. 15, p. 7596.

[30] Brunner P.; Hendricks Franssen H.-J; Kgotlhang L. Bauer-Gottwein P. et Kinzelbach W. (2007) How can remote sensing contribute in groundwater modeling?; Hydrogeology Journal, $n^{\circ} .15$, p. 5-18.

[31] Leblanc M., Favreau G. Sarah T., Leduc C., Razack M., and Mofor L. (2007) Remote sensing for groundwater modelling in large semiarid areas: Lake Chad Basin, Africa. Hydrogeology journal, vol. 15, p. 97-100.

[32] Sander P. (2007) Lineaments in groundwater exploration: a review of applications and limitations, Hydrogeology Journal, $\mathrm{n}^{\circ} 15$, p. $71-74$.

[33] Suh, C. E., Lehmann, B., \& Mafany, G. T. (2006). Geology and geochemical aspects of lode gold mineralization at DimakoMboscorro SE Cameroon. Geochemistry: Exploration, Environment, Analysis, 6, 295-309.

[34] Kankeu, B. (2008). Anisotropie de la susceptibilité magnétiqueg $(\mathrm{AM})$ et fabrique des roches néoprotérozoïques des régions de Garga-Sarali et Betaré-Oya a l'Est du Cameroun implications geodynamique pour l'evolution de la Chaîne panafricaine d'Afrique Centrale. Thèse de Doctorat $/ \mathrm{Ph}$. D, Univerté de Yaoundé I, 159p. et al., 2008

[35] Ateh K., Suh C. E., Shemang E. M., Vishiti A., Tata E., Chombong N. N., 2017. New LA-ICP-MS U-Pb Ages, Lu-Hf Systematics and REE Characterization of Zircons from a Granitic Pluton in the Betare Oya Gold District, SE Cameroon. Journal of Geosciences and Geomatics, 5, 6, 267-283.

[36] Vishiti, A., Suh, C. E., Lehmann, B., Egbe, J. A., Shemang, E. M., Gold grade variation and particle microchemistry in exploration pits of the Batouri gold district, SE Cameroon. Journal of African Earth Sciences 111, 1-13, 2015.

[37] Ndong B. F., Ntomba, S. M., Mvondo, O. J. 2014a. Définition structurale des linéaments par traitement d'image satellitaire: cas du massif de Ngovayang (Sud Cameroun). Afrique Science $10,3,107-112$.

[38] Nédélec, A., Bouchez, J. L. 2011. Pétrologie des granites: structure, cadre géologique. Soc. Geo. France, 306p.

[39] Belanger, M., 1995. contrôle struqural et confexte métallogénique de l'indice aurifere dorset, peninsule de baie verte, terre-neuve. Mem. Maitrise, Université du Québec, INRS-Géoressources, 95p

[40] Bélanger, M., Dubé, B. et Lauzière, K. 1992. "A prelirninary report of the structural control of the mesothermal Dorset gold showing, Baie Verte Peninsula, Newfoundland". Newfoudland Department of Mines and Energy, Report of Activities 1992, p. $3-4$.

[41] Colvine, A. C., Andrews, A. J., Cherry, M. E., Durocher, M. E., Fyon, A. J., Lavigne, M. J., Macdonald, A. J., Marmont, S., Poulsen, K. H., Springer, J. S. et Troop, D. G. 1984. "An integrated model for the origin of Archean Iode gold deposits". Ontario Geological Survey, Open File Report 5524, 98 p. 
[42] Colvine, A. C., Fyon, K. B., Heather, K. B., Marmont, S., Smith, P. M. et Troop, D. G. 1988. "Archean Iode gold deposit in Ontario". Ontario Geological Survey, Miscellaneous Paper $139,136 \mathrm{p}$.

[43] Cox, S. P., Wall, V. J., Etheridge, M'A. et Potter, T. F. 1991. "Deformational and metamorphic processes in the formation of mesothermal vein-hosted gold depositsexemples from the Lachlan Fold Belt in central Victoria, Australia". Ore Geology Review, Volume 6, p. 391-423.

[44] Groves, D. 1., Barley, M. E. et Ho, S. E. 1990. "Nature genesis and tectonic setting of mesothermal gold mineralization in the Yilgarn Block, Western Australia". The Geology of the gold deposits: The perspective in 1988. Édité par RR Keays, W. RH. Ramsay et D. I. Grove. Economic Geology, Monograph 6, p. 71-95.

[45] Bélanger, M. Dubé, B., Lauzière, K. et Malo, M. 1993. "Structural Control of the mesothermal Dorset Gold showing, Baie Verte Peninsula, Newfoundland". Newfoundland Department of Mines and Energy, Report of Activities 1993, p. 57-59.

[46] Hall, R. S. et Rigg, D. M. 1986. "Geology of the West Anticline Zone, Musselwhite Prospect, Opapimaskan Lake, Ontario, Canada". Proceeding of Gold '86. an International Symposium on the Geology of Gold. Édité par A. J Macdonald, Konsult International Inc., Toronto, p. 124-136.
[47] Savané, I. (1997) Contribution à l'étude géologique et hydrogéologique des aquifères discontinus du socle cristallin d'Odienné Nord- Ouest de la Côte d'Ivoire). Apports de la télédétection et d'un Système d'Information Hydrogéologique à Référence Spatiale. Thèse de doctorat ès Sciences Naturelles, Université d'Abidjan- Côte d'Ivoire, 386 p.

[48] Jourda J. P. (2005) Méthodologie d'application des techniques de télédétection et des systèmes d'information géographique à l'étude des aquifères fissurés d'Afrique de l'ouest. Concept de l'Hydrotechniquespatiale: cas des zones tests de la Côte d'Ivoire. Thèse de doctorat ès Sciences Naturelles, Université de Cocody-Abidjan, Côte d'Ivoire, 429 p.

[49] Seward, T. M. 1981. "Metal complex formation in aqueous solutions at elevated temperatures and pressures". Chemistry and Geochemistry of Solutions at high Temperatures and Pressure. Édité par D. T. Rickard et F. E. Wickman. Permagon, Oxford, p. 113-128.

[50] Romberger, S. B. 1986. "The solution chemistry of gold applied to the origin of hydrothermal deposits". Gold in the Western Shield. Édité par L. A. Clark. Canadian Institute of Mining and Metallurgy, Special Volume 38, p. 168-186.

[51] T. M. Seward, The formation of lead (II) chloride complexes to $300^{\circ} \mathrm{C}$ : A spectrophotometric study. Geochimica et Cosmochimica Acta, 1984 - Elsevier. Volume 48, Issue 1, Pages 121-134. 